\title{
GROWTH AND SURVIVAL OF SEEDLINGS AND SAPLINGS IN THE LOGGED - OVER FOREST, KINTAP, SOUTH KALIMANTAN
}

\author{
Yusuf S. Jafarsidik $^{1}$
}

\begin{abstract}
A study on demography, growth and survival of seedlings and saplings was conducted in the Hutan Kintap concenssion, South Kalimantan, Indonesia. The aim of the study was to monitor pattern of growth of seedlings and saplings among different types of logged - over forest, including the newly logged - forest, older logged - over forests (treated and untreated), and un-logged-forest patches. The study began in 1991, and nineteen of 0.25 ha plots were set up in a total of six blocks designated as consecutively $\mathrm{A}, \mathrm{B}, \mathrm{C}, \mathrm{D}$, $\mathrm{E}$ and F. Block A was a newly logged forest and had five plots, and Block B-D were in forest which had been logged in 1979. Block B (five plots) had received no silvicultural treatment, while Block C (five plots) and $\mathrm{D}$ (one plot) had been lightly thinned after felling and further Block $\mathrm{C}$ received a further thinning treatment. Block E (one plot) had been heavily thinned, and Block F (2 plots) was an un-logged control. The density of seedling varied within the study sites, and averaged from $47,000 \mathrm{ha}^{-1}$ to $121,000 \mathrm{ha}^{-1}$. The mean height increment of seedlings varied among block ranging from $2.9 \mathrm{~cm}$ year ${ }^{-1}$ to $10.5 \mathrm{~cm}$ year $\mathrm{r}^{-1}$. Block A had the highest general mean increment of $10.5 \mathrm{~cm}_{\text {year }}{ }^{-1}$, followed in decreasing order by Block $\mathrm{C}$ of 5.4 and Block F, $4.5 \mathrm{~cm}_{\text {year }}{ }^{-1}$. Growth of seedling in Block B was low, even lower than the growth in the un-logged Block F. The difference of the increment among Block A, B, C and F however was not significant. The liberation treatment in Block $C$ significantly resulted in a higher $(p<0.01)$ increment $\left(5.4 \mathrm{~cm}\right.$ year $\left.{ }^{-1}\right)$ than that in the untreated Block B $\left(2.9 \mathrm{~cm}_{\text {year }}{ }^{-1}\right)$. Seedling mortality ranged from 16 to $37 \%$ year ${ }^{-1}$, and declined with height class. The mortality of seedlings might be related among other factors to the humidity and density of seedlings per-unit area. The density of sapling ranged from $6,800 \mathrm{ha}^{-1}$ to $7,700 \mathrm{ha}^{-1}$ and they had diameter growth of $0.8 \mathrm{~mm}_{\text {year }}{ }^{-1}$ to $2.2 \mathrm{~mm}_{\mathrm{yer}}{ }^{-1}$, and height growth of $12.6 \mathrm{~cm}_{\text {year }}^{-1}$ to $21.8 \mathrm{~cm}$ year $\mathrm{r}^{-1}$. The difference in the diameter increment among block $\mathrm{A}, \mathrm{B}, \mathrm{C}$ and $\mathrm{F}$ was not significant. The average sapling height increment varied (but not significantly so) among Block, ranging from $12.6 \mathrm{~cm}$ year ${ }^{-1}$ in Block A to $21.8 \mathrm{~cm}_{\text {year }}{ }^{-1}$ in Block C. Mortality of sapling was relatively low in all block. Higher mortality in the un-logged forest Block $\mathrm{F}$ and in the untreated Block B might due to the low degree of canopy opening.
\end{abstract}

Keywords: seedling, growth, mortality, dipterocarp, pioneers, logged-over forest

\section{INTRODUCTION}

Regeneration after logging depends among other factors on the availability, pattern of growth, and survivorship of seedlings and saplings remaining on the forest floor or germinated from dispersed seeds and from seeds deposited in the soil seed bank.

Forest trees may be divided into: climax species (shade bearers) of which the seeds may germinate and establish in the shade, although they may respond with rapid growth when the forest canopy is opened, and pioneer species which germinated, establish and complete their life cycle in large gaps (Whitmore, 1984; Brokaw, 1985; Swaine and Whitmore, 1988). Regeneration after logging involves both species groups and to some extent simulates the regeneration in large natural gaps.

Growth of seedlings under the closed canopy of virgin forest is slow (Popma and Bongers, 1988; Turner, 1990) whereas in a logged-over forest seedling growth may be markedly higher.

1 Forest and Nature Conservation Research and Development Center, Bogor 
Nicholson (1958) indicated that the large openings caused by heavy logging induced the growth of dipterocarp seedlings, with larger seedlings, responding more than smaller ones, whereas about $40 \%$ of seedlings in virgin forest were almost dormant. Growth of seedlings in the gaps increased with light intensity (Popma and Bongers, 1988; Whitmore, 1989; Turner, 1990). Light intensity in this case may correspond to the size of the gaps, the larger the gap the higher the intensity of light on the gaps floor. Species composition in gaps, either from formerly suppressed seedling and sapling or from germinating seeds, is determined by growth and mortality associated with gap-size variation, individual species density, and other factors such as shading from the earlier growing trees (inhibiting pioneer seedlings), root competition, and pattern of flowering and fruiting (frequently recruitment after mass fruiting generally have longer-lived seedling) (Whitmore, 1984 ; 1986; Connell, 1989). Survivorship varies between species (Liew and Wong, 1973; Turner, 1990).

Growth response of seedlings and saplings following logging depends on canopy opening and on the species composition. An area dominated by dipterocarps and or pioneer seedlings and saplings may have higher growth rates in response to the canopy openings. The species groups (canopy, sub canopy and under-story species) may respond differently to light intensity.

The study aimed to verify the pattern of growth and survival of seedlings and saplings in the forest plots logged in 1979 or 1991, and compared it to the un-logged forest patches.

\section{MATERIALS AND METHODS}

\section{A. Study Area}

Kintap forest is about $90 \mathrm{~km}$ South-East of Banjarmasin, the Provincial capital of South Kalimantan. It lies between $3^{\circ} 40^{\prime}-3^{\circ} 45^{\prime} \mathrm{S}$ and $115^{\circ}-115^{\circ} 30^{\prime} \mathrm{E}$, and has a rugged topography with the altitude up to $200 \mathrm{~m}$ above sea level.

This study set up 19 plots, divided into blocks $A$ of the newly logged-over forest (logged in 1991, plots were set up 15 days after logging, designated as plot No.1 - 5), B of the twelve years old logged-over forest (logged in 1979, undergoing iron wood removal by local people, plot No. 6 - 10), C the same as block B but received liberation treatment in 1991 (all lianas were cut and trees of Macaranga were killed by girdling, plot No. 11 -15), D (plot No. 16) same as C with liberation done in 1985 and no ironwood removal, E (plot No. 17) same as D but liberation was done at least twice a year after 1985 (intensive liberation) and F (plot No. 18 and 19) was not logged for dipterocarps but experienced ironwood removal.

\section{B. Quadrate Setting and Enumeration}

Seedling ( $<2 \mathrm{~m}$ high) heights were measured in a $1 \mathrm{~m}$ by $1 \mathrm{~m}$ quadrate, randomly set up in every $10 \mathrm{~m} \mathrm{x} 10 \mathrm{~m}$ subplot in each plot of $50 \mathrm{~m} \times 50 \mathrm{~m}$. Sapling heights ( $=2 \mathrm{~m}$ heights $-<$ $10 \mathrm{~cm}$ diameter) were measured in every quadrate of $5 \mathrm{~m} \mathrm{x} 5 \mathrm{~m}$ randomly set up in a randomly selected $10 \mathrm{~m}$ x $10 \mathrm{~m}$ subplot on every 10-m wide strip (arranged north-south) of the $50 \mathrm{~m} \times$ $50 \mathrm{~m}$ plot. The total area of seedling quadrate was $25 \mathrm{~m}^{2}$ per plot, and that of sapling quadrate was $125 \mathrm{~m}^{2}$ per plot. All seedlings and saplings were labeled.

The enumeration of seedlings and saplings in the newly logged-forest Block A (plots 1 5) was done on 17 December 1991, 20 June 1992, and 11 December 1992 (total 12 months), and in the rest of the plot (plots 6 - 19) on December 1991 and 18 September 1993 (total 20 months). Mortality was recorded at the same time as the measurements. 


\section{RESULTS}

\section{A. Seedlings}

The numbers of individual seedling in Block A (newly logged forest) varied between plots, the highest being in plot 3 with 260 seedlings and the least in plot 5 with 143 seedlings in the first enumeration (Table 1). The total number of seedlings in all five plot was 924 with the average of 185 per plot (in $25 \mathrm{~m}^{2}$ ), equivalent to a density of $73,920 \mathrm{ha}^{-1}$.

The individual mean increase in height growth varied among plots, both in the first and second six months. The highest mean increase occurred in plot 1 , followed in decreasing order by plot 5 , plot 4 , until the least in plot 2 (Table 1 ). The difference in the increment between plots tested by a one-way ANOVA was highly significant $(p<0.01)$, this was due to the large difference between plot 1 and the others.

Mortality in the newly logged forest varied among plots with the highest in plot 3 with $36.5 \%$ in the first six months (Table 1 ). The difference in mortality among plots in the newly logged forest was significant $(p<0.05)$.

Numbers of individual seedling in the first enumeration (December 1991) varied between blocks with the average per plot ranging from 171 (Block C) to 303 (Block F) (Table 1 and 2)

Table 1 . Height increment $(\mathrm{cm})$ and mortality (\%) of seedlings in the newly logged forest (site A), December 1991 - December 1992 (12 months)

\begin{tabular}{|c|c|c|c|c|c|c|c|c|c|}
\hline \multirow[t]{3}{*}{ Plot } & \multirow{2}{*}{\multicolumn{3}{|c|}{$\begin{array}{l}\text { Mean height increment } \\
(\mathrm{cm})\end{array}$}} & \multicolumn{6}{|c|}{ Mortality } \\
\hline & & & & \multicolumn{3}{|c|}{$N$} & \multicolumn{3}{|c|}{$\%$} \\
\hline & $\begin{array}{l}\text { First six } \\
\text { months } \\
\text { June } \\
1992 \text { ) }\end{array}$ & $\begin{array}{c}\text { Second six } \\
\text { months } \\
\text { (Decembe } \\
1992)\end{array}$ & Overall & $\begin{array}{c}\text { Dec } \\
1991\end{array}$ & $\begin{array}{l}\text { June } \\
1992\end{array}$ & $\begin{array}{c}\text { Dec } \\
1992\end{array}$ & $\begin{array}{l}\text { June } \\
1992\end{array}$ & $\begin{array}{l}\mathrm{Dec} \\
1992\end{array}$ & $\begin{array}{l}\text { Overall } \\
\left.\text { (year }{ }^{-1}\right)\end{array}$ \\
\hline 1 & 13.1 & 12.6 & $25.7^{* *}$ & 150 & 131 & 124 & 12.7 & 5.3 & 17.3 \\
\hline 2 & 2.4 & 1.5 & 3.9 & 189 & 152 & 137 & 18.5 & 9.7 & 26.5 \\
\hline 3 & 2.8 & 2.7 & 4.5 & 260 & 173 & 165 & 33.5 & 4.6 & $36.5^{*}$ \\
\hline 4 & 4.2 & 4.3 & 8.5 & 182 & 155 & 151 & 14.8 & 2.6 & 17 \\
\hline 5 & 4.9 & 8.9 & 13.8 & 143 & 104 & 100 & 27.2 & 3.8 & 30.1 \\
\hline $\begin{array}{l}\text { General } \\
\text { mean }\end{array}$ & 5.5 & 5.5 & 10.5 & 184.8 & 143 & 135.4 & 21.3 & 5.2 & 25.5 \\
\hline
\end{tabular}

Remark: * significant $(p<0.05)$

** highly significant $(p<0.01)$

The mean height increment of seedlings varied among blocks (Tables 1 and 2). Block A had the highest general mean increment of $10.5 \mathrm{~cm}$ year ${ }^{-1}$, followed by Block $C$ of 5.4 and Block $\mathrm{F}, 4.5 \mathrm{~cm}$ year $^{-1}$. Growth of seedlings in Block B was low, even lower than the growth in the unlogged Block $\mathrm{F}$ (Table 2). The difference of the increment among Blocks $\mathrm{A}, \mathrm{B}, \mathrm{C}$ and $\mathrm{F}$ however was not significant.

The liberation treatment in Block $C$ resulted in a higher $(p<0.01)$ increment $(5.4 \mathrm{~cm}$ year $\left.{ }^{-1}\right)$ that the untreated Block B $\left(2.9 \mathrm{~cm}\right.$ year $\left.{ }^{-1}\right)$. Plots 16 (Block D) and 17 (Block E) had been set up to determine the relative effects of intensive liberation (Block E) compared to light 
liberation treatment (Block D). There was no significant difference in the mean individual increment between the two plots (Table 2). The height increment and mortality with initial seedling height in Blocks A, B and F are shown in Table 3. The increment generally increased with the initial height in every block except that in the un-logged forest Block $\mathrm{F}$ where the increment declined at the height class $120-149.9 \mathrm{~cm}$ (Fig.1).

The average annual mortality varied little among Block A, B, C and F, ranging from $23.9 \%$ (Block B) to $26.6 \%$ (Block C) (Table 1 and 2). Mortality was higher in Block E (22.2\% year ${ }^{-1}$ ) compared to that in Block D $\left(16,3 \%\right.$ year $\left.^{-1}\right)$.

Table 2. Height increment (cm) and mortality (\%) of seedling in sites B, C, D, E and F, December 1991 - September 1993 (20 months).

\begin{tabular}{|c|c|c|c|c|c|c|c|c|}
\hline \multirow{3}{*}{ Block } & \multirow{3}{*}{ Plot } & \multicolumn{3}{|c|}{ Height $(\mathrm{cm})$} & \multicolumn{4}{|c|}{ Mortality } \\
\hline & & \multirow{2}{*}{$\begin{array}{l}\text { First } \\
\text { average } \\
(\mathrm{cm})\end{array}$} & \multicolumn{2}{|c|}{$\begin{array}{c}\text { Mean increment } \\
(\%)\end{array}$} & \multirow[t]{2}{*}{$N_{1}$} & \multirow[t]{2}{*}{$\mathrm{N}_{2}$} & \multirow{2}{*}{$\begin{array}{c}\text { In } 20 \\
\text { months } \\
(\%)\end{array}$} & \multirow{2}{*}{$\begin{array}{l}\text { Year }^{1} \\
(\%)\end{array}$} \\
\hline & & & $\begin{array}{l}\text { In } 20 \\
\text { months }\end{array}$ & Year ${ }^{-1}$ & & & & \\
\hline \multirow[t]{6}{*}{ B } & 6 & 29.9 & 5.1 & 3.1 & 232 & 125 & 46.1 & 27.7 \\
\hline & 7 & 29.9 & 4.3 & 2.6 & 271 & 155 & 42.8 & 25.7 \\
\hline & 8 & 30.2 & 3.4 & 2 & 233 & 154 & 33.9 & 20.3 \\
\hline & 9 & 33.1 & 6.1 & 3.7 & 215 & 121 & 43.7 & 26.2 \\
\hline & 10 & 35.4 & 5.5 & 3.3 & 220 & 147 & 33.2 & 19.9 \\
\hline & Mean & & & 2.9 & 234.2 & 140.9 & & 23.9 \\
\hline \multirow[t]{6}{*}{$\mathrm{C}$} & 11 & 18.7 & 10 & 6.0 & 348 & 133 & 61.8 & 37.1 \\
\hline & 12 & 24.2 & 7.8 & 5.0 & 155 & 72 & 53.2 & 31.9 \\
\hline & 13 & 25.7 & 10.1 & 6.1 & 147 & 93 & 36.5 & 21.9 \\
\hline & 14 & 33.5 & 8.8 & 5.3 & 117 & 84 & 28.8 & 17.3 \\
\hline & 15 & 28.5 & 7.6 & 4.6 & 86 & 50 & 41.9 & 25 \\
\hline & Mean & & & 5.4 & 170.6 & 86.4 & & 26.6 \\
\hline$D$ & 16 & 42.5 & 6.9 & 4.1 & 118 & 86 & 27.1 & 16.3 \\
\hline$E$ & 17 & 35 & 9.8 & 5.9 & 211 & 133 & 37.0 & 22.2 \\
\hline \multirow[t]{3}{*}{$F$} & 18 & 28.1 & 6.6 & 4 & 285 & 162 & 42.8 & 25.7 \\
\hline & 19 & 26.3 & 4.9 & 4.9 & 321 & 188 & 41.4 & 24.8 \\
\hline & Mean & & & 4.5 & 303 & 175 & & 25.3 \\
\hline
\end{tabular}

Table 3. Height increment $\left(\mathrm{cm}_{\text {year }}{ }^{-1}\right)$ and mortality $\left(\%\right.$ year $\left.{ }^{-1}\right)$ of seedling by height class in site $A, B$ and $F$

\begin{tabular}{|c|c|c|c|c|c|c|c|c|c|c|c|c|}
\hline \multirow{3}{*}{$\begin{array}{c}\text { Height class } \\
(\mathrm{cm})\end{array}$} & \multicolumn{4}{|c|}{ Block A } & \multicolumn{4}{|c|}{ Block B } & \multicolumn{4}{|c|}{ Block F } \\
\hline & \multicolumn{3}{|c|}{ Mortality } & \multirow[t]{2}{*}{ Increment } & \multicolumn{3}{|c|}{ Mortality } & \multirow[t]{2}{*}{ Increment } & \multicolumn{3}{|c|}{ Mortality } & \multirow[t]{2}{*}{ Increment } \\
\hline & $N_{1}$ & $\mathrm{~N}_{2}$ & $\%$ & & $\mathrm{~N}_{1}$ & $\mathrm{~N}_{2}$ & $\%$ & & $N_{1}$ & $\mathrm{~N}_{2}$ & $\%$ & \\
\hline$<5 \quad-29.9$ & 563 & 344 & 38.9 & 7.4 & 795 & 395 & 30.2 & 2 & 435 & 124 & 30.5 & 4.3 \\
\hline $30-59.9$ & 204 & 184 & 9.6 & 11.8 & 196 & 154 & 12.8 & 3 & 116 & 86 & 14 & 4.7 \\
\hline $60-89.9$ & 67 & 62 & 7.5 & 10.3 & 92 & 75 & 11.1 & 4.3 & 33 & 27 & 10.9 & 10.3 \\
\hline $90-119.9$ & 44 & 44 & 0 & 12.6 & 49 & 43 & 7.3 & 5.6 & 15 & 13 & 8 & 7.9 \\
\hline $120-149.9$ & 28 & 28 & 0 & 18.8 & 17 & 16 & 3.5 & 7.6 & 6 & 6 & 0 & 21.7 \\
\hline $150-179.9$ & 11 & 10 & 9.1 & 19.8 & 13 & 11 & 9.2 & 5.9 & 1 & 1 & 0 & 5 \\
\hline$>180$ & 7 & 7 & 0 & 22.8 & 9 & 8 & 6.7 & 4.7 & - & - & - & - \\
\hline
\end{tabular}




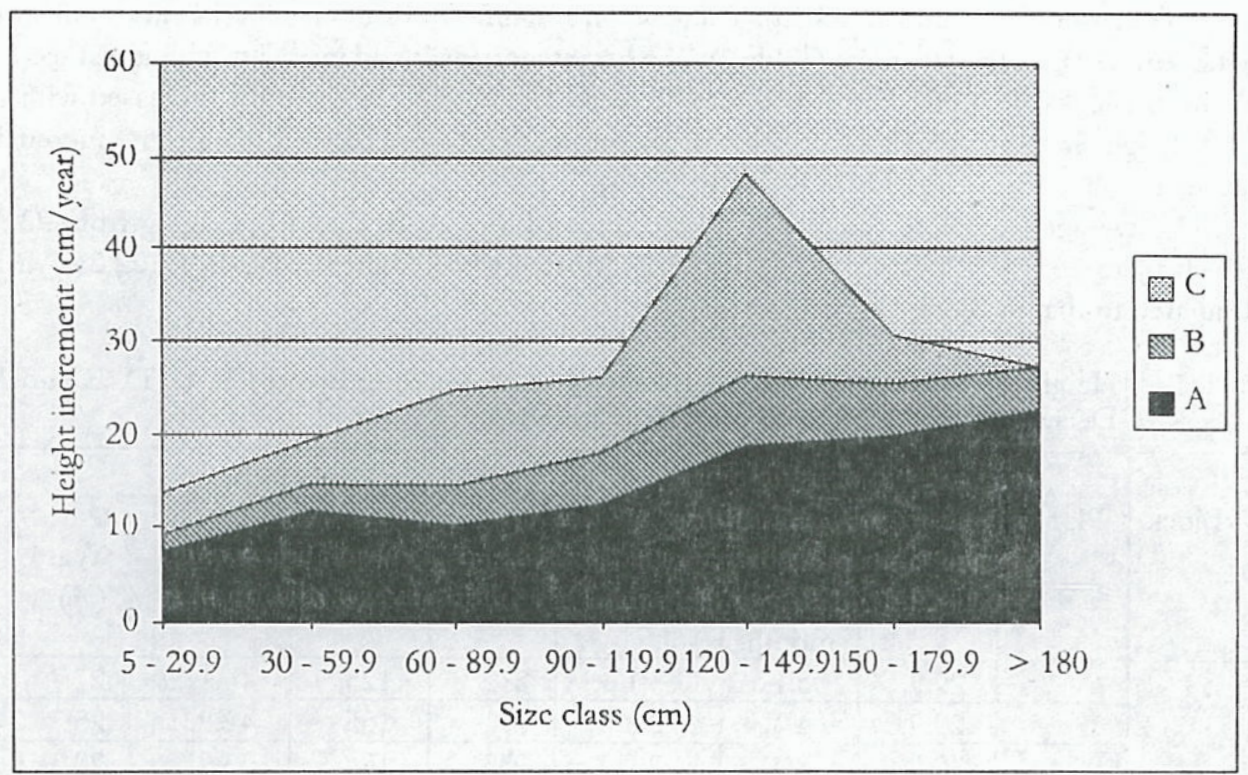

Figure 1. Initial height size classes (1991) of the seedlings and their corresponding height increment in Blocks $\mathrm{A}, \mathrm{B}$ and $\mathrm{F}$.

Increment and mortality of dipterocarps are compared to non-dipterocarps in Table 4. There were differences in the average annual increment of dipterocarps between Blocks A, B and $F$, with the highest increment in Block $A$. The difference in the average annual increment of dipterocarps was highly significant $(p<0.01)$. There was no difference in the dipterocarp seedling height increment between Block B and Block F, as indicated in the Tukey's test.

Canopy, subcanopy and understorey species might respond differently to canopy opening. Table 5 shows the increment and mortality of species in these categories by the Block $A, B$ and F. The species category was primarily based on the species grouping by Korning and Balslev (1994). The canopy, subcanopy and understory seedling had the highest increment in Block A where the understory seedling species had a highest increment than the canopy and subcanopy seedling. The understory species had a much higher increment in Block A than in B and F. The difference was highly significant $(p<=0.01)$, suggesting that seedling of the understory species responded more to the canopy opening than under the shade in their earlier establishment. The mortality of the three species categories differed little among the three Blocks (Table 5).

Table 4. Diptrocarp and non-dipterocarp increment $\left(\mathrm{cm}^{\circ}\right.$ year $\left.^{-1}\right)$ and mortality $\left(\%\right.$ year $\left.{ }^{-1}\right)$ of seedling in Blocks $A, B$ and $F$

\begin{tabular}{|c|c|c|c|c|c|c|c|c|c|c|c|c|}
\hline & \multicolumn{4}{|c|}{ Block A } & \multicolumn{4}{|c|}{ Block B } & \multicolumn{4}{|c|}{ Block F } \\
\hline & \multicolumn{3}{|c|}{ Mortality } & \multirow[t]{2}{*}{ Increment } & \multicolumn{3}{|c|}{ Mortality } & \multirow[t]{2}{*}{ Increment } & \multicolumn{3}{|c|}{ Mortality } & \multirow[t]{2}{*}{ Increment } \\
\hline & $N_{1}$ & $\mathrm{~N}_{2}$ & $\%$ & & $N_{1}$ & $\mathrm{~N}_{2}$ & $\%$ & & $N_{1}$ & $\mathrm{~N}_{2}$ & $\%$ & \\
\hline Dipterocarp & 108 & 89 & 17.6 & $16.8^{* *}$ & 249 & 130 & 28.7 & 3.0 & 200 & 100 & 30.0 & 3.9 \\
\hline Non-dipterocarp & 816 & 590 & 27.7 & 8.9 & 922 & 572 & 37.9 & 2.8 & 411 & 254 & 38.2 & 4.7 \\
\hline
\end{tabular}

Remarks: ${ }^{* *}$ highly. significant $\cdot(p<0.01)$ 
Table 5. Canopy, subcanopy and understorey species seedlings increment ( $\mathrm{cm}$ year $\left.\mathrm{r}^{-1}\right)$ and mortality $\left(\%\right.$ year $\left.^{-1}\right)$ in sites $\mathrm{A}, \mathrm{B}$ and $\mathrm{F}$.

\begin{tabular}{|c|c|c|c|c|c|c|c|c|c|c|c|}
\hline & \multicolumn{4}{|c|}{ Block A } & \multicolumn{4}{|c|}{ Block B } & \multicolumn{3}{|c|}{ Block F } \\
\hline & \multicolumn{3}{|c|}{ Mortality } & \multirow[t]{2}{*}{ Increment } & \multicolumn{3}{|c|}{ Mortality } & \multirow[t]{2}{*}{ Increment } & \multicolumn{2}{|c|}{ Mortality } & \multirow[t]{2}{*}{ Increment } \\
\hline & $N_{1}$ & $\mathrm{~N}_{2}$ & $\%$ & & $\mathrm{~N}_{1}$ & $\mathrm{~N}_{2}$ & $\%$ & & $\begin{array}{ll}N_{1} & N_{2}\end{array}$ & $\%$ & \\
\hline Canopy & 364 & 270 & 25.8 & 9.2 & 397 & 232 & 25.0 & 3.1 & 281144 & 29.3 & 4.5 \\
\hline Sub-canopy & 213 & 143 & 32.9 & 7.0 & 381 & 230 & 23.8 & 2.2 & 16286 & 28.1 & 4.8 \\
\hline Understory & 270 & 201 & 25.6 & $11.2^{* * *}$ & 230 & 147 & 21.7 & 3.0 & 10871 & 20.6 & 4.6 \\
\hline
\end{tabular}

Remarks: ** highly significant $(p<0.01)$

The pattern of growth and mortality of the six commonest species is shown in Table 6. All species grew slightly faster in Block A than in Block B, and in Block F the species grew slightly faster than in Block B except Hopea sangal and Xanthopbyllum beteropleurum. The dipterocarp species Hopea sangal and Shorea parvistipulata had a higher increment in Block A and showed no difference in the other blocks. This indicates that both species grow faster under canopy openings. The six species included only one subcanopy species (Hydnocarpus polypetalus) and one understory species (Polyalthyia celebica). The understory species Polyalthia celebica grew faster in Block A $\left(3.6 \mathrm{~cm}\right.$ year $\left.^{-1}\right)$ and in Block $\mathrm{F}\left(2.7 \mathrm{~cm}_{\text {year }}{ }^{-1}\right)$ compared to Block B $\left(1.8 \mathrm{~cm}\right.$ year $\left.{ }^{-1}\right)$. High mortality occurred in species with denser individuals (Table 6).

Table 6. Increment $\left(\mathrm{cm}\right.$ year $\left.{ }^{-1}\right)$ and mortality $\left(\%\right.$ year $\left.^{-1}\right)$ of the six commonest seedling species $(=10$ individuals) in Block $\mathrm{A}, \mathrm{B}$ and $\mathrm{F}$

\begin{tabular}{|l|l|c|c|c|l|}
\hline Site & Species & Increment & \multicolumn{3}{|c|}{ Mortality } \\
\cline { 3 - 5 } & & & $\mathrm{N}_{1}$ & $\mathrm{~N}_{2}$ & \multicolumn{1}{c|}{$\%$} \\
\hline \multirow{2}{*}{ A } & Dacryodes rostrata & 5.8 & 67 & 29 & 56.7 \\
& Hopea sangal & 18.5 & 20 & 14 & 30 \\
& Hydnocarpus polypetalus & 7.0 & 14 & 11 & 21.4 \\
& Polyalthia celebica & 3.6 & 34 & 24 & 29.4 \\
& Shorea parvistipulata & 23.9 & 23 & 22 & 4.3 \\
& Xanthopbyllum beteropleurum & 2.2 & 11 & 10 & 9.1 \\
\hline \multirow{5}{*}{ B } & Dacryodes rostrata & 1.9 & 12 & 8 & 20.0 \\
& Hopea sangal & 4.9 & 64 & 30 & 31.9 \\
& Hydnocarpus polyptalus & 2.9 & 14 & 14 & 0 \\
& Polyaltbia celebica & 1.8 & 35 & 20 & 25.7 \\
& Shorea parvistipulata & 2.8 & 66 & 34 & 29.1 \\
& Xanthopbyllum beterpleurum & 1.4 & 20 & 16 & 12 \\
\hline F & Dacryodes rostrata & 2.5 & 23 & 9 & 36.4 \\
& Hopea sangal & 2.9 & 71 & 36 & 29.6 \\
& Hydnocarpus polyp & 3.6 & 25 & 15 & 24 \\
& Polyalthia celebica & 2.7 & 18 & 8 & 33.4 \\
& Shorea parvistipulata & 3.4 & 96 & 50 & 28.7 \\
& Xanthopbyllum beterpleurum & 1.1 & 11 & 10 & 5.5 \\
\hline
\end{tabular}




\section{B. Saplings}

The total number of individual sapling did not differ very much between Blocks $A(7,776$ $\left.\mathrm{ha}^{-1}\right), \mathrm{B}\left(7,632 \mathrm{ha}^{-1}\right)$ and $\mathrm{F}\left(6,840 \mathrm{ha}^{-1}\right)$, however the number of individuals in Block C $\left(2,704 \mathrm{ha}^{-1}\right)$ was much lower than in A, B and F (Table 7). The low number of sapling in Block $\mathrm{C}$ was due to the liberation treatment by the concessionaires in 1991 . Block D had 8640 saplings $\mathrm{ha}^{-1}$.

The overall mean diameter increment was low in all blocks, ranging from $0.8 \mathrm{~mm}^{-1} \mathrm{r}^{-1}$ in Block $\mathrm{F}$ to $2.2 \mathrm{~mm}$ year ${ }^{-1}$ in Block $\mathrm{C}$ (Table 7). The difference in the diameter increment among Blocks $\mathrm{A}, \mathrm{B}, \mathrm{C}$ and $\mathrm{F}$ was not significant. There was a difference in the diameter increment among plots in Block $\mathrm{A}$ with the highest was in plot 1 . The difference was significant $(p<0.05)$. The average sapling height increment varied (but not significantly so) among blocks, ranging from $12.6 \mathrm{~cm}$ year ${ }^{-1}$ in Block $A$ to $21.8 \mathrm{~cm}$ year in Block C (Table 7).

Table 7. Height $\left(\mathrm{cm}_{\text {year }}{ }^{-1}\right)$ and diameter $\left(\mathrm{mm}\right.$ year $\left.{ }^{-1}\right)$ increment, and mortality $\left(\%\right.$ year $\left.{ }^{-1}\right)$ of saplings in Blocks A - F.

\begin{tabular}{|c|c|c|c|c|c|c|c|}
\hline \multirow[b]{2}{*}{ Site } & \multirow[b]{2}{*}{ Plot } & \multicolumn{3}{|c|}{ Mortality } & & \multicolumn{2}{|c|}{ Mean increment } \\
\hline & & $\mathrm{N}_{1}$ & $\mathrm{~N}_{2}$ & $\%$ & & $\begin{array}{l}\text { Height } \\
\left(\mathrm{cm} \text { year }^{-1}\right)\end{array}$ & $\begin{array}{l}\text { Diameter } \\
\left(\mathrm{mm}^{2} \text { yer }^{-1}\right)\end{array}$ \\
\hline \multirow[t]{6}{*}{ A } & 1 & 66 & 66 & 0 & & 10 & $1.9^{*}$ \\
\hline & 2 & 209 & 207 & 0.9 & & 18 & 0.6 \\
\hline & 3 & 87 & 87 & 0 & & 10 & 0.5 \\
\hline & $\sim 4$ & 74 & 74 & 0 & & 10 & 1.1 \\
\hline & 5 & 50 & 49 & 2.0 & & 15 & 1.1 \\
\hline & Total & 486 & 483 & 0.62 & Overall mean & 12.6 & 1.0 \\
\hline \multirow[t]{6}{*}{ B } & 6 & 72 & 70 & 1.7 & & 14 & 0.7 \\
\hline & 7 & 88 & 86 & 1.5 & & 21 & 0.8 \\
\hline & 8 & 54 & 52 & 2.1 & & 20 & 0.9 \\
\hline & 9 & 146 & 140 & 2.5 & & 20 & 1.1 \\
\hline & 10 & 11 & 110 & 3.8 & & 20 & 2.0 \\
\hline & Total & 477 & 458 & 2.39 & Overall mean & 19.0 & 1.1 \\
\hline \multirow[t]{6}{*}{$\mathrm{C}$} & 11 & 34 & 34 & 0 & & 41 & 2.5 \\
\hline & 12 & 34 & 33 & 1.7 & & 20 & 1.3 \\
\hline & 13 & 44 & 44 & 0 & & 17 & 1.0 \\
\hline & 14 & 42 & 39 & 4.3 & & 17 & 2.9 \\
\hline & 15 & 15 & 15 & 0 & & 14 & 3.2 \\
\hline & Total & 169 & 165 & 1.42 & Overall mean & 21.8 & 2.2 \\
\hline $\mathrm{D}$ & 16 & 108 & 103 & 2.77 & & 23 & 1.3 \\
\hline$E$ & 17 & 103 & 97 & 3.50 & & 25 & 2.5 \\
\hline \multirow[t]{3}{*}{$\mathrm{F}$} & 18 & 86 & 81 & 3.5 & & 12 & 0.6 \\
\hline & 19 & 85 & 83 & 1.4 & & 18.6 & 0.9 \\
\hline & Total & 171 & 164 & 2.46 & Overall mean & 16.8 & 0.8 \\
\hline
\end{tabular}

Remarks: * significant $(\mathrm{p}<0.05)$

The canopy opening resulting from the recent logging in Blok A did not result in both greater mean height and diameter increment of sapling in this Block. Height increment in Block A was the lowest in all sites, and the diameter increment was only slightly higher than the diameter increment in Block F (un-logged forest) (Table 7). Block D however the mean diameter increment in plot 17 of $2.5 \mathrm{~mm}$ year ${ }^{-1}$ was significantly $(p<0.05)$ higher than in plot 16 of $1.3 \mathrm{~mm}_{\text {year }}{ }^{-1}$ (Table 7).The difference indicated a significant effect of the liberation treatment on sapling 
diameter increment in plot 17. Mortality of saplings was ranked Block E> D $>F>B>$

A.

The number of dipterocarp sapling varied among blocks with the highest in Block B (61 sapling) and the least in Block C (8 sapling) (Table 8). The low number of dipterocarp sapling in Block $\mathrm{C}$ indicated a faulty liberation treatment (from the concessionaires malpractice). Mean height and diameter increment of the dipterocarps did not differ significantly among blocks. The diameter growth increment of dipterocarps in Block $A$ and $C$ was higher than non-dipterocarps, whereas in Blocks B, D, E, and F it were lower (Table 8). Non dipterocarps in Block B consisted partly of pioneer tree species which showed higher growth than primary tree species (including dipterocarps) (Table 9). There were twelve pioneer tree species in Block B, mostly Macaranga spp., with an average height increment ranging from 2 to $53 \mathrm{~cm}$ year ${ }^{-1}$ and a diameter increment from $0.3 \mathrm{~mm} \mathrm{year}^{-1}$ (Enodia aromatica) to $6.1 \mathrm{~mm}^{-1} \mathrm{rar}^{-1}$ (Macaranga sp). (Table 11). The mortality of the pioneers was low, with only one tree (out of 67) dying in 20 months (Table 9).

In Block B the average height increment of pioneer $\left(22 \mathrm{~cm}_{\text {year }} \mathrm{C}^{-1}\right)$ (Table 9) was slightly lower than of the dipterocarp ( $25 \mathrm{~cm}_{\text {year }}{ }^{-1}$ ) (Table 8 ), but the average diameter increment of the pioneer of $2.7 \mathrm{~mm}$ year ${ }^{-1}$ was much higher than that of dipterocarps with $1.0 \mathrm{~mm}$ year. The difference was significant $(p<0.01)$. The height increment of the pioneer species did not differ much from the shade-bearing species in this site, whereas the mean diameter increment of the pioneers of $2.7 \mathrm{~mm}$ year ${ }^{-1}$ was significantly $(p<0.01)$ higher than of the shade-bearing species of $1.1 \mathrm{~mm}^{-1}$ year ${ }^{-1}$ Table 9).

Table 8. Dipterocarp and non-dipterocarp sapling growth increment

\begin{tabular}{|c|c|c|c|c|c|c|c|c|c|c|}
\hline \multirow[t]{3}{*}{ Block } & \multicolumn{5}{|c|}{ Dipterocarps } & \multicolumn{5}{|c|}{ Non-dipterocarps } \\
\hline & \multicolumn{3}{|c|}{ Mortality } & \multicolumn{2}{|c|}{ Increment } & \multicolumn{3}{|c|}{ Mortality } & \multicolumn{2}{|c|}{ Increment } \\
\hline & $N_{1}$ & $\mathrm{~N}_{2}$ & $(\%$ year -1$)$ & $\begin{array}{c}\text { Height } \\
(\mathrm{cm} \text { year }-1)\end{array}$ & $\begin{array}{c}\text { Diameter } \\
(\mathrm{mm} \text { year- } 1)\end{array}$ & $N_{1}$ & $\mathrm{~N}_{2}$ & $(\%$ year -1$)$ & $\begin{array}{c}\text { Height } \\
(\mathrm{cm} \text { year }-1)\end{array}$ & $\begin{array}{c}\text { Diameter } \\
\text { (mm year- } 1 \text { ) }\end{array}$ \\
\hline$A$ & 30 & 29 & 3.33 & 21 & 1.3 & 456 & 454 & 0.44 & 13 & 0.9 \\
\hline B & 61 & 60 & 1.02 & 25 & 1 & 416 & 398 & 2.58 & 18 & 1.4 \\
\hline C & 8 & 8 & 0 & 22 & 2.4 & 161 & 157 & 1.49 & 22 & 2 \\
\hline D & 29 & 29 & 0 & 29 & 1.1 & 79 & 74 & 3.8 & 22 & 1.3 \\
\hline$E$ & 27 & 27 & 0 & 29 & 2.2 & 76 & 70 & 4.7 & 23 & 2.6 \\
\hline $\mathrm{F}$ & 10 & 10 & 0 & 17 & 0.3 & 161 & 154 & 2.61 & 17 & 0.8 \\
\hline Average & & & 1.09 & 21.8 & 1.3 & & & 1.78 & 17.5 & 1.2 \\
\hline
\end{tabular}

Table 9. Growth increment and mortality of pioneer and primary forest species in Block B

\begin{tabular}{|l|c|c|c|c|c|}
\hline \multirow{2}{*}{ Species } & \multicolumn{3}{|c|}{ Mortality } & \multicolumn{2}{c|}{ Mean Increment } \\
\cline { 2 - 6 } & $\mathrm{N}_{1}$ & $\mathrm{~N}_{2}$ & $(\%$ year- 1$)$ & $\begin{array}{c}\text { Height } \\
(\mathrm{cm} \text { year- } 1)\end{array}$ & $\begin{array}{c}\text { Diameter } \\
(\mathrm{mm} \text { year-1 })\end{array}$ \\
\hline Pioneer species & 67 & 66 & 0.89 & 22 & $2.7^{* *}$ \\
Shadebearing species & 410 & 392 & $2.63^{*}$ & 18 & 1.1 \\
\hline
\end{tabular}

Remarks: * significant $(p<0.05)$

** highly significant $(p<0.01)$ 
The growth of the dipterocarp species in Block B is given in Table 10. Shorea johorensis had the highest diameter increment of $1.6 \mathrm{~mm}_{\text {year }}{ }^{-1}$ followed by Shorea parvifolia with $1.3 \mathrm{~mm}$ year ${ }^{1}$. Both the species are relatively fast growing dipterocarps, included in Shorea-section Brachypterae (Shorea "Red Meranti group") (Ashton,1982).

In the unlogged forest (Block F) the height increment of the dipterocarps was the same as the non-dipterocarps, whereas the diameter increment was on the contrary (Table 8). This implies that the diameter growth of the dipterocarp saplings in the virgin forest was very low.

Table 10. Growth increment of dipterocarps in Block B.

\begin{tabular}{|l|c|c|}
\hline \multirow{2}{*}{\multicolumn{1}{|c|}{ Species }} & \multicolumn{2}{|c|}{ Increment } \\
\cline { 2 - 3 } & $\begin{array}{c}\text { Diameter } \\
\text { (mm year-1) }\end{array}$ & $\begin{array}{c}\text { Height } \\
\text { (cm year-1) }\end{array}$ \\
\hline Dipterocarpus hasseltii & 1.1 & 10 \\
Hopea sangal & 0.7 & 37 \\
Shorea parvistipulata & 0.7 & 14 \\
Shorea johorensis & 1.6 & 43 \\
Shorea parvifolia & 1.3 & 32 \\
\hline
\end{tabular}

Pioneers in Block B had a higher average diameter $(28.4 \mathrm{~mm})$ and height $(5.01 \mathrm{~m})$ than dipterocarps at the first and second enumeration (Table 12). The mortality of saplings was low in all sites. The percentage mortality in Block B $\left(2.39 \%\right.$ year $\left.{ }^{-1}\right)$ did not differ very much from Block F $\left(2.46 \%\right.$ year $\left.^{-1}\right)$, both were much higher than in Block A $\left(0,62 \%\right.$ year $\left.^{-1}\right)$ (Table 7$)$. The difference in percentage mortality between Blocks $\mathrm{A}, \mathrm{B}$ and $\mathrm{F}$ however was not significant.

The average mortality of dipterocarps per Block $\left(1.09 \%\right.$ year $\left.{ }^{-1}\right)$ was not significantly lower than that of non-dipterocarps $\left(1.78 \%\right.$ year $\left.^{-1}\right)$ (Table 8$)$. Pioneer tree saplings had less mortality than primary tree species in Block B with $0.89 \%$ year $^{-1}$ compared to $2.63 \%$ year-1 (Table 9).

Table 11. Growth increment and mortality of pioneer tree species in Block B

\begin{tabular}{|c|c|c|c|c|c|c|}
\hline \multirow[t]{2}{*}{ No } & \multirow[t]{2}{*}{ Species } & \multicolumn{3}{|c|}{ Mortality } & \multicolumn{2}{|c|}{ Mean Increment } \\
\hline & & $\mathrm{N}_{1}$ & $\mathrm{~N}$ & $\left(\%\right.$ year $\left.^{-1}\right)$ & $\begin{array}{c}\text { Height } \\
\left(\mathrm{cm} \text { year }^{-1}\right)\end{array}$ & $\begin{array}{l}\text { Diameter } \\
\left(\mathrm{mm}^{2} \text { year }{ }^{-1}\right)\end{array}$ \\
\hline 1 & Cananga odorata (Annonaceae) & 1 & 1 & 0 & 20 & 0.5 \\
\hline 2 & Euodia aromatica (Rutaceae) & 1 & 1 & 0 & 27 & 0.3 \\
\hline 3 & Gevunsia pentandra (Verbenaceae) & 1 & 1 & 0 & 33 & 0.8 \\
\hline 4 & Glochidion sp. (Euphorbiaceae) & 3 & 2 & 1 & 16 & 1.1 \\
\hline 5 & Homalanthus populneus (Euphorbiaceae) & 2 & 2 & 0 & 2 & 1.5 \\
\hline 6 & Macaranga conferta (Euphorbiaceae) & 3 & 3 & 0 & 13 & 1.1 \\
\hline 7 & Macaranga diepenhorstii (Euphorbiaceae) & 13 & 13 & 0 & 26 & 1.1 \\
\hline 8 & Macaranga gigantea (Euphorbiaceae) & 10 & 10 & 0 & 16 & 1 \\
\hline 9 & Macaranga bypoleuca (Euphorbiaceae) & 2 & 2 & 0 & 5 & 1.1 \\
\hline 10 & Macaranga sp. (Euphorbiaceae) & 2 & 2 & 0 & 53 & 6.1 \\
\hline 11 & Macaranga triloba (Euphorbiaceae) & 11 & 11 & 0 & 21 & 1.8 \\
\hline 12 & Mallotus subpeltatus (Euphorbiaceae) & 18 & 18 & 0 & 35 & 5.8 \\
\hline & Total & 67 & 66 & & & \\
\hline
\end{tabular}


The difference in mortality between the pioneer and the primary species in Block B was highly significant $(p<0.01)$. The mortality in Block B (Table 7$)$ was wholly of primary species, except in plot 10 where one pioneer sapling died. Diameter increment increased with size class in sites $A, B$ and $F$ until the $40 \mathrm{~mm}$ class and the declined at the $60 \mathrm{~mm}$ class, whereas mortality occurred particularly for saplings in size class $40-59.9 \mathrm{~mm}$ and lower. None of the saplings in size class $60-79.9 \mathrm{~mm}$ and above died (Table 13).

Table 12. Comparison of the average height and diameter between dipterocarps and pioneers in Block $B$ in the first enumeration

\begin{tabular}{|l|c|c|c|c|}
\hline \multirow{2}{*}{ Description } & \multicolumn{2}{|c|}{ Dipterocarps } & \multicolumn{2}{c|}{ Pioneers } \\
\cline { 2 - 5 } & $\begin{array}{c}\text { Height } \\
(\mathrm{m})\end{array}$ & $\begin{array}{c}\text { Diameter } \\
(\mathrm{mm})\end{array}$ & $\begin{array}{c}\text { Height } \\
(\mathrm{m})\end{array}$ & $\begin{array}{c}\text { Diameter } \\
(\mathrm{mm})\end{array}$ \\
\hline Mean & 4.04 & 20.1 & 5.01 & 28.4 \\
\hline Minimum & 2.03 & 5.7 & 2.04 & 5.8 \\
\hline Maximum & 11.5 & 76.0 & 13.6 & 95.0 \\
\hline Median & 3.76 & 17.1 & 4.62 & 22.8 \\
\hline
\end{tabular}

Table 13. Diameter increment (mm year- 1 ) and mortality (\% year- 1 ) of saplings by size-class in Block A, B and F

\begin{tabular}{|c|c|c|c|c|c|c|c|c|c|c|c|c|}
\hline \multirow{3}{*}{$\begin{array}{l}\text { Size class } \\
(\mathrm{mm})\end{array}$} & \multicolumn{4}{|c|}{ Block A } & \multicolumn{4}{|c|}{ Block B } & \multicolumn{4}{|c|}{ Block F } \\
\hline & \multicolumn{3}{|c|}{ Mortality } & \multirow[t]{2}{*}{ Increment } & \multicolumn{3}{|c|}{ Mortality } & \multirow[t]{2}{*}{ Increment } & \multicolumn{3}{|c|}{ Mortality } & \multirow[t]{2}{*}{ Increment } \\
\hline & $N_{1}$ & $\mathrm{~N}_{2}$ & $\%$ & & $N_{1}$ & $\mathrm{~N}_{2}$ & $\%$ & & $N_{1}$ & $\mathrm{~N}_{2}$ & $\%$ & \\
\hline$<10-19.9$ & 294 & 293 & 0.3 & 0.7 & 265 & 255 & 2.3 & 1.0 & 102 & 98 & 2.4 & 0.7 \\
\hline $20-39.9$ & 137 & 136 & 0.7 & 0.8 & 132 & 124 & 3.6 & 1.4 & 46 & 43 & 3.9 & 0.7 \\
\hline $40-59.9$ & 36 & 35 & 2.8 & 2.0 & 52 & 51 & 1.2 & 2.5 & 12 & 12 & 0 & 1.4 \\
\hline $60-79.9$ & 16 & 16 & 0 & 1.6 & 23 & 23 & 0 & 2.3 & 9 & 9 & 0 & 0.9 \\
\hline $80-99.9$ & 3 & 3 & 0 & 1.2 & 5 & 5 & 0 & 1.3 & 2 & 2 & 0 & 0.5 \\
\hline
\end{tabular}

\section{DISCUSSION}

The seedling bank is important in forest regeneration after disturbance. The density of seedling stock varies with forest type, soil and topography. In this study, seedling density varied among blocks and among plots of the the same block. The density of seedlings in the newly logged forest (Block A) for instance may to some extent be related to topography since the least density of seedlings occurred on steep slope in plot 5 (Table 1).

In Block $A$ most seedlings could be derived from the existing seedlings before logging in August 1990, whereas in other logged-over Blocks seedlings may be derived mostly from the later recruits (seedling germinated from the freshly dispersed seeds) after logging 12 years before.

The highest increment in plot 1 may be due to one or all of a lower density of trees $=10$ $\mathrm{cm} \mathrm{dbh}$, relatively bigger canopy openings and relatively less disturbed plots (bare soil in this plot was not very compacted). Plot 2 was also lightly disturbed, but had more shade after re-growth following an earlier light logging in 1987. 
The height increment of seedlings was ranked in Block $A>F>B$ (Table 14). The height increment in Block A could be due to the canopy opening after recent logging, particularly in plot 1.The lower increment in Block B than in Block F may due to a stage of forest development in this block after the 1979 logging in which the forest floor was more shaded.

Table 14. Density, increment and mortality of seedlings in Blocks A-F.

\begin{tabular}{|c|c|c|c|}
\hline Block & Density $\left(\mathrm{ha}^{-1}\right), 1991$ & Increment $\left(\mathrm{cm}^{-1}\right.$ year $\left.^{-1}\right)$ & Mortality $\left(\%\right.$ year $\left.^{-1}\right)$ \\
\hline A & 73,920 & 10.5 & 25.5 \\
\hline B & 93,680 & 2.9 & 23.9 \\
\hline C & 68,240 & 5.4 & 26.6 \\
\hline D & 47,200 & 4.1 & 16.3 \\
\hline E & 84,400 & 5.9 & 22.2 \\
\hline F & 121,200 & 4.5 & 25.3 \\
\hline
\end{tabular}

The canopy opening resulting from the liberation treatment in Block $\mathrm{C}$ also caused a significantly higher increment than the untreated Block B.

The highest in plot 3 of Block A may due to the least disturbance with the least canopy opening, having shade and humidity similar to the virgin forest where the seedlings are vulnerable to pathogens (Connell,1989; Turner,1990). Mortality in all plots was much higher in the first six months (average $21.3 \%$ ) compared to the second six months $(5.2 \%)$ (Table. 1 ). This condition could be related to the humidity. December 1991 - July 1992 were wet while August - November $1992 \mathrm{had}$ much less rainfall (Appendices 1 and 2).

The mortality of seedlings among blocks differed little. The least mortality in site D $(16.3 \%)$ could be related to the relatively lower density of seedling (Tables 2 and 14). Heavy mortality following the abundance of seedlings could be due to severe competition. Mortality declined with height class (Table 3) confirming Turner's (1990) suggestion that it was size dependent.

There may be variation among dipterocarp seedlings in their response to canopy opening (Baur, 1964; Liew and Wong, 1973). Certain seedling species like Shorea multiflora keeps growing under the shade on the floor of virgin forest (Turner, 1990). In this study, the dipterocarp species Hopea sangal and Shorea pavistipulata had much higher increments than non-dipterocarps in the newly logged forest (Block A) (Table 6 ), whereas in Blocks B and F the two groups differed little. Both species may need light for their establishment since the canopy opening in Block $A$ was more than in Blocks $B$ and $F$.

The understorey species in this study showed more response to the canopy opening than the canopy and sub-canopy species. The understory species is an important stage for the pollinating insects to react canopy-top during mass flowering.

Sapling stocking did not differ very much between blocks except in Block $C$ which had a liberation treatment. The stocking (excluding Block $C$ ) ranged from about $6,800-8,600 \mathrm{ha}$. In plot 2 of the newly logged-forest Block A the number of saplings was 209 ( $16,700 \mathrm{ha}$ ). The high number of the saplings of this plot may due to the re-growth after logging in this plot in 1987.

Nicholson (1965) noted the uncertainty of sapling (advance regeneration) growth after logging. The uncertainty of sapling growth may due to the condition of the logged-over forest. In this study, saplings did respond to canopy openings caused by logging, even though the growth was slow. Plot 1 in Block $A$ had the widest canopy openings, and had the highest sapling diameter growth within the Block C, compared to the other blocks (Table 7). The lower increment of saplings in the logged-over forest may be due to stronger competition with larger trees which 
respond better to canopy openings.

The growth of the pioneer sapling was higher than that of dipterocarp sapling. Pioneer sapling were only present in the 12 years old logged-over forest, particularly in Block B, whereas pioneer seedlings were already scarce, indicating that the role of pioneers was diminishing at the age (Kuusipalo et al., 1996).

Low growth rates of saplings in logged-over forest may indicate a different pattern of response to canopy openings from that in natural tree fall gaps. Competition of saplings with larger trees in the natural tree fall gaps may be less than that in the logged-over forest resulting in vigorous gap growth of saplings formerly suppressed under the closed canopy.

\section{CONCLUDING REMARKS}

Seedling density ha-1 (dipterocarps in parenthese) ranged from 47,000 (8,600) in the newlylogged forests Block $A$ to $121,000(40,000)$ in Block F. Higher increment $(10.5 \mathrm{~cm}$ year-1) of seedlings in the newly-logged forest Block A may be related to the greater degree of canopy opening following the logging. The liberation treatment (removal of pioneer trees) in Block C was accompanied by a higher increment $\left(5.4 \mathrm{~cm}\right.$ year- $\left.{ }^{-1}\right)$ of both dipterocarp and non-dipterocarp seedlings compared with the untreated Block B $(2.9 \mathrm{~cm}$ year-1). Even the understorey species showed a strong response to increase light (Table 5). The species with the highest density showed the highest seedling mortality (Table 4).

The sapling stock varied from $6,800 \mathrm{ha}^{-1}$ to $8,600 \mathrm{ha}-1$. diameter growth ranged from 0.8 $\mathrm{mm}$ (un-logged forest patch Block F) to $2.2 \mathrm{~mm}$ year-1 in the treated 12 years old logged-over forest Block $\mathrm{C}$. The growth may be partly related to canopy opening.

\section{REFERENCES}

Brokaw, N. V. L 1985. Gap phase regeneration in tropical forest. Ecology 66: 682-687. Connell, J. H. 1989. Some processes affecting the species composition in forest gap. Ecology 70: $560-562$.

Korning, J. and Balslev, H. 1994. Growth rates and mortality patterns of tropical lowland tree species and the relation to forest structure in Amazonia Equador. Journal of tropical Ecology 10: 151 - 166.

Kuusipalo, J., Y. Jafarsidik, G. Adjers, and K. Tuomela. 1996. Population dynamics of tree seedlings in a mixed dipterocarp rainforest before and after logging and crown liberation. Forest Ecology and Management 81: 85 - 94.

Liew, T.C and F.O. Wong. 1973. Density, recruitment, mortality and growth of Dipterocarp seedling in virgin and logged-over forests in Sabah. Malaysian Forester 36: $3-15$.

Nicholson, D. I. 1958. Natural regeneration of logged tropical rain forest, North Borneo. Malayana Forester 21: $235-245$.

Nicholson, D. I. 1965. A review of natural regeneration in the dipterocarp forest of Sabah. Malayana Forest 28: 4 - 26.

Popma, J. and F. Bongers. 1988. The effect of canopy gaps on growth and morphology of seedlings of rain forest species. Oecologia 75: $625-632$.

Swaine, M. D. and T.C. Whitmore. 1988. On the definition of ecological species groups in tropical rain forest. Vegetation 75: $81-86$. 
Turner, I. M. 1990a. The seedling survivorship and growth of three Shorea species in a Malaysian tropical rain forest. Journal of Tropical Ecology 6: $469-478$.

Turner, I. M. 1990b. Tree seedling growth and survival in a Malaysian rain forest. Biotropica 22: $146-154$.

Uhl, C., K. Clark, N. Dezzo and Maquirino 1988. Vegetation dynamics in Amazonian treefall gaps. Ecology 69: $751-154$.

Whitmore, T. C. 1984. Tropical Rain Forests of the Far East 2nd edition. Clarendon Press. Oxford.

Whitmore, T. C. 1986. Forest dynamics and question of scale. Rain Forest Regeneration and Management. Report of a workshop (ed. M. Hadley), pp. 13 - 15. Biology International, Special Issue 18.

Whitmore, T. C. 1989. Canopy gaps and two major group of forest trees Ecology 70: 536 - 538. 
Appendix 1. Precipitation $(\mathrm{P})$ and number of rain days (Nrd) recorded at Pelaihari, South Kalimantan, 1979 - 1995.

\begin{tabular}{|c|c|c|c|c|c|c|c|c|c|c|c|c|c|}
\hline \multirow{2}{*}{ Year } & \multicolumn{12}{|c|}{ Month } & \multirow{2}{*}{ Total } \\
\hline & $\begin{array}{c}1 \\
\mathrm{P} \\
\mathrm{Nrd} \\
\end{array}$ & 2 & 3 & 4 & 5 & 6 & 7 & 8 & 9 & 10 & 11 & 12 & \\
\hline \multirow[t]{2}{*}{1979} & 467 & 179 & 251 & 108 & 334 & 155 & 135 & 189 & 134 & 107 & 156 & 418 & 2633 \\
\hline & 15 & 8 & 15 & 9 & 13 & 9 & 8 & 6 & 9 & 7 & 11 & 15 & 125 \\
\hline \multirow[t]{2}{*}{1980} & 480 & 389 & 232 & 440 & 61 & 205 & 19 & 34 & 5 & 68 & 450 & 477 & 2860 \\
\hline & 22 & 14 & 14 & 18 & 9 & 10 & 3 & 5 & 7 & 6 & 17 & 21 & 146 \\
\hline \multirow[t]{2}{*}{1981} & 490 & 292 & 138 & 350 & 270 & 121 & 140 & 0 & 241 & 135 & 962 & 612 & 3751 \\
\hline & 15 & 10 & 6 & 9 & 11 & 3 & 9 & 0 & 7 & 8 & 17 & 18 & 113 \\
\hline \multirow[t]{2}{*}{1982} & 770 & 320 & 308 & 310 & 135 & 188 & 7 & 0 & 6 & 23 & 68 & 341 & 2476 \\
\hline & 18 & 13 & 19 & 13 & 3 & 4 & 1 & 0 & 2 & 3 & 7 & 18 & 101 \\
\hline \multirow[t]{2}{*}{1983} & 407 & 320 & 269 & 258 & 188 & 93 & 192 & 54 & 23 & 180 & 880 & 655 & 3519 \\
\hline & 14 & 14 & 12 & 14 & 11 & 8 & 14 & 4 & 6 & 11 & 18 & 14 & 140 \\
\hline \multirow{2}{*}{1984} & 454 & 261 & 655 & 402 & 241 & 132 & 213 & 33 & 227 & 133 & 154 & 694 & 3599 \\
\hline & 21 & 22 & 19 & 22 & 20 & 10 & 10 & 3 & 9 & 5 & 12 & 21 & 174 \\
\hline \multirow[t]{2}{*}{1985} & 521 & 489 & 425 & 144 & 173 & 112 & 100 & 120 & 25 & 98 & 365 & 377 & 2949 \\
\hline & 15 & 13 & 16 & 12 & 14 & 4 & 4 & 6 & 6 & 5 & 13 & 11 & 119 \\
\hline \multirow[t]{2}{*}{1986} & 321 & 179 & 276 & 120 & 106 & 100 & 142 & 0 & 22 & 206 & 179 & 194 & 1836 \\
\hline & 19 & 15 & 25 & 15 & 8 & 12 & 11 & 0 & 5 & 14 & 17 & 17 & 158 \\
\hline \multirow[t]{2}{*}{1987} & 470 & 303 & 362 & 161 & 400 & 147 & 64 & 6 & 0 & 29 & 217 & 489 & 2648 \\
\hline & 24 & 17 & 23 & 9 & 15 & 7 & 3 & 1 & 0 & 4 & 11 & 16 & 130 \\
\hline \multirow[t]{2}{*}{1988} & 398 & 396 & 438 & 105 & 109 & 100 & 160 & 314 & 331 & 229 & 243 & 550 & 3373 \\
\hline & 21 & 21 & 22 & 13 & 15 & 8 & 11 & 18 & 16 & 12 & 18 & 23 & 198 \\
\hline \multirow[t]{2}{*}{1989} & 533 & 429 & 330 & 213 & 263 & 145 & 241 & 35 & 104 & 231 & 450 & 643 & 3617 \\
\hline & 21 & 21 & 16 & 19 & 15 & 11 & 7 & 5 & 7 & 17 & 17 & 20 & 176 \\
\hline \multirow[t]{2}{*}{1990} & 198 & 309 & 204 & 160 & 268 & 27 & 62 & 14 & 3 & 40 & 185 & & 1470 \\
\hline & 15 & 19 & 19 & 15 & 19 & 5 & 10 & 4 & 2 & 10 & 10 & & 128 \\
\hline \multirow[t]{2}{*}{1991} & 508 & 255 & 173 & 231 & 257 & 67 & 3 & 38 & 0 & 45 & 245 & 374 & 2196 \\
\hline & 27 & 15 & 14 & 16 & 11 & 3 & 2 & 3 & 0 & 4 & 17 & 21 & 172 \\
\hline \multirow[t]{2}{*}{1992} & 206 & 433 & 334 & 307 & 247 & 169 & 217 & 26 & 83 & 276 & 282 & 525 & 3105 \\
\hline & 20 & 15 & 16 & 18 & 14. & 9 & 18 & 2 & 6 & 14 & 19 & 21 & 172 \\
\hline \multirow[t]{2}{*}{1993} & 352 & 332 & 221 & 192 & 198 & 160 & 37 & 0 & 2 & 130 & 168 & 453 & 2245 \\
\hline & 17 & 20 & 21 & 11 & 18 & 18 & 5 & 0 & 1 & 5 & 15 & 20 & 151 \\
\hline \multirow[t]{2}{*}{1994} & 267 & 281 & 310 & 157 & 135 & 698 & 82 & 40 & & 12 & 143 & 226 & 2351 \\
\hline & 20 & 17 & 23 & 15 & 8 & 15 & 3 & 3 & & 1 & 15 & 14 & 134 \\
\hline \multirow[t]{2}{*}{1995} & 446 & 325 & 288 & 235 & 267 & 290 & 226 & 198 & 81 & 137 & 565 & 568 & 3626 \\
\hline & 17 & 15 & 10 & 17 & 12 & 14 & 10 & 11 & 6 & 6 & 15 & 22 & 155 \\
\hline \multirow[t]{2}{*}{ Average } & 428 & 323 & 307 & 229 & 215 & 171 & 120 & 65 & 80 & 122 & 336 & 475 & 2871 \\
\hline & 19 & 16 & 17 & 14 & 13 & 9 & 8 & 4 & 6 & 8 & 15 & 18 & 146 \\
\hline
\end{tabular}


Appendix 2. The average humidity (\%) at Pelaihari, South Kalimantan, 1981 - 1995

\begin{tabular}{|c|c|c|c|c|c|c|c|c|c|c|c|c|}
\hline \multirow[b]{2}{*}{ Year } & \multicolumn{12}{|c|}{ Month } \\
\hline & 1 & 2 & 3 & 4 & 5 & 6 & 7 & 8 & 9 & 10 & 11 & 12 \\
\hline 1981 & 91 & 83 & 86 & 87 & 88 & 81 & 87 & 79 & 82 & 83 & 85 & 87 \\
\hline 1982 & 89 & 88 & 85 & 89 & 86 & 84 & 74 & 74 & 70 & 70 & 77 & 82 \\
\hline 1983 & 87 & 85 & 86 & 84 & 86 & 87 & 83 & 77 & 77 & 82 & 87 & 87 \\
\hline 1984 & 91 & 86 & 89 & 90 & 89 & 86 & 84 & 79 & 83 & 81 & 86 & 86 \\
\hline 1985 & 90 & 84 & 85 & 86 & 87 & 84 & 84 & 82 & 80 & 79 & 85 & 85 \\
\hline 1986 & 85 & 83 & 86 & 85 & 82 & 84 & 81 & 72 & 74 & 82 & 84 & 84 \\
\hline 1987 & 87 & 85 & 82 & 82 & 87 & 78 & 77 & 71 & 69 & 70 & 85 & 86 \\
\hline 1988 & 88 & 87 & 87 & 84 & 85 & 81 & 84 & 86 & 86 & 84 & 86 & 85 \\
\hline 1989 & 88 & 88 & 88 & 85 & 86 & 89 & 84 & 78 & 81 & 86 & 88 & 89 \\
\hline 1990 & 87 & 87 & 86 & 84 & 8 & 81 & 83 & 78 & 72 & 74 & 78 & 89 \\
\hline 1991 & 88 & 87 & 86 & 87 & 87 & 82 & 75 & 72 & 67 & 69 & 80 & 89 \\
\hline 1992 & 85 & 76 & 84 & 84 & 84 & 82 & 89 & 74 & 87 & 80 & 85 & 94 \\
\hline 1993 & 84 & 85 & 85 & 87 & 84 & 81 & 79 & 69 & 68 & 70 & 83 & 84 \\
\hline 1994 & 86 & 85 & 85 & 85 & 79 & 85 & 81 & 72 & 68 & 68 & 79 & 82 \\
\hline 1995 & 83 & 84 & 83 & 85 & 81 & 84 & 82 & 79 & 76 & 78 & 84 & 84 \\
\hline Average & 87 & 85 & 86 & 86 & 85 & 83 & 82 & 76 & 76 & 77 & 83 & 86 \\
\hline
\end{tabular}

